\title{
Ribulose-1,5-bisphosphate Carboxylase from Rhodomicrobium vannielii
}

\author{
By S. C. TAYLOR AND C. S. DOW \\ Department of Biological Sciences, University of Warwick, Coventry CV4 $7 A L$
}

(Received 23 April 1979; revised 21 June 1979)

\begin{abstract}
The effect of carbon growth substrate on the level of ribulose-1,5-bisphosphate (RuBP) carboxylase in crude cell-free extracts of Rhodomicrobium vannielii (RM5) was investigated. The highest specific activity followed growth with sodium hydrogen malate as carbon source. Cells grown autotrophically or on the reduced carbon substrates, butyrate and ethanol, gave extracts of lower activity. RuBP carboxylase was purified from $R$. vannielii (RM5) grown on a mixture of pyruvate and malate as carbon source. The enzyme was homogeneous as judged by electrophoresis on polyacrylamide gels of several acrylamide concentrations and had an apparent molecular weight of 430000 as measured by gel filtration. Sodium dodecyl sulphate polyacrylamide gel electrophoresis suggested the presence of three subunit types of molecular weights 56200,53300 and $15700 . \mathrm{Mg}^{2+}$ was required for maximum enzyme activity although this could be completely replaced by $\mathrm{Ni}^{2+}$ and, to a lesser extent, by $\mathrm{Mn}^{2+}$ or $\mathrm{Co}^{2+}$. As with other high molecular weight $\mathrm{RuBP}$ carboxylases, the enzyme was sensitive to inhibition by 6-phosphogluconate.
\end{abstract}

\section{INTRODUCTION}

Ribulose-1,5-bisphosphate (RuBP) carboxylase (EC 4.1.1.39) is the primary catalyst of the reductive pentose phosphate cycle (Calvin cycle) for $\mathrm{CO}_{2}$ assimilation (Bassham et al., 1954). Because of its key role in this cycle and the diversity of organisms within which it is found, there is considerable interest in its structure and properties.

All RuBP carboxylases so far examined contain a large polypeptide (mol. wt 52000 to 58000) on which the catalytic site resides (McFadden \& Tabita, 1974). Enzymes purified from Thiocapsa (McFadden, 1977), Rhodospirillum rubrum (Tabita \& McFadden, 1974a), Chlorobium (Tabita et al., 1974a) and certain cyanobacteria (Tabita et al., 1974b, 1976) are reported to be made up solely of this large polypeptide subunit having one, two, six and eight copies, respectively. The majority of RuBP carboxylases, however, also contain multiple copies of a small polypeptide with a molecular weight between 12000 and 20000 (McFadden, 1973). This small polypeptide is believed to have a regulatory function (Takabe \& Akazawa, 1973). Where both are present, the available evidence suggests that there is a 1:1 mole ratio of large to small subunits, as in the RuBP carboxylases of Chromatium D (Akazawa et al., 1972), Ectothiorhodospira halophila (Tabita \& McFadden, 1976), Anabaena variabilis (Takabe et al., 1976), the eukaryotic algae and higher plants. These carboxylases all have molecular weights of approximately 550000 and consist of eight large plus eight small subunits. The RuBP carboxylase of Pseudomonas oxalaticus contains only six large and six small subunits (McFadden, 1977).

Two forms of RuBP carboxylase have been reported in Rhodopseudomonas sphaeroides (Gibson \& Tabita, 1977a) and Rhodopseudomonas capsulata (Gibson \& Tabita, 1977b). One form has a high molecular weight (550000) and contains both large and small subunits; the second has a lower molecular weight (360000) and contains only large subunits. 
Rhodomicrobium vannielii exhibits a complex life cycle in which $\mathrm{CO}_{2}$ has been implicated as a controlling factor (France, 1978). As part of an investigation into the role and regulation of $\mathrm{CO}_{2}$ fixation in $R$. vannielii and other Rhodospirillaceae, we have purified the RuBP carboxylase from this organism and examined some of its properties.

\section{METHODS}

Growth. Rhodomicrobium vannielii strain RM5 was grown on a salts medium plus $1.5 \mathrm{~g}$ each of sodium pyruvate and sodium hydrogen malate, adjusted to $\mathrm{pH} 6.8$ with $\mathrm{KOH}$ (Whittenbury \& Dow, 1977). For enzyme purification, cultures were grown in 201 flasks sealed with rubber serum caps, flushed with $\mathrm{O}_{2}$-free $\mathrm{N}_{2}$ and incubated with stirring at $30^{\circ} \mathrm{C}$ under constant illumination from tungsten lamps (incident light intensity, $2000 \mathrm{~lx}$ ). For measuring enzyme activity following growth on various carbon substrates, $200 \mathrm{ml}$ cultures were grown in $250 \mathrm{ml}$ shake flasks on the salts medium supplemented with carbon substrate as indicated. After flushing with $\mathrm{O}_{2}$-free $\mathrm{N}_{2}$, cultures were incubated as above and harvested in the midexponential phase of growth.

Enzyme assay and measurement of protein concentration. RuBP carboxylase was assayed at $30^{\circ} \mathrm{C}$ in a reaction mixture $(0.25 \mathrm{ml}$ final vol.) which contained $15 \mu \mathrm{mol} \mathrm{Tris} / \mathrm{HCl}, \mathrm{pH} 8.2$ (unless stated otherwise), $2.5 \mu \mathrm{mol} \mathrm{MgCl}{ }_{2} \cdot 6 \mathrm{H}_{2} \mathrm{O}, 5 \mu \mathrm{mol} \mathrm{NaH}{ }^{14} \mathrm{CO}_{3}$ (sp. act. $0 \cdot 8 \mu \mathrm{Ci} \mu \mathrm{mol}^{-1}$ ) and enzyme. Any further additions were as indicated in Results. After preincubation for $5 \mathrm{~min}$, the reaction was started by adding $0.2 \mu \mathrm{mol}$ RuBP, and it was stopped after a further $5 \mathrm{~min}$ by adding $100 \mu \mathrm{l} 12 \mathrm{M}$-formic acid. Any precipitate was removed by centrifugation. A $200 \mu \mathrm{l}$ sample of the final reaction mixture was evaporated to dryness in a scintillation vial, resuspended in $1 \mathrm{ml}$ water and radioactivity (fixed ${ }^{14} \mathrm{C}$ ) was measured in a liquid scintillation spectrometer with a Triton/toluene scintillation fluid. One unit of enzyme activity catalyses the RuBP-dependent fixation of $1 \mu \mathrm{mol} \mathrm{CO} \mathrm{Cmin}^{-1}$. Specific activity is expressed in units (mg protein) ${ }^{-1}$. Protein concentrations were determined with the Folin-Ciocalteau reagent (Kennedy \& Fewson, 1968) with dried crystalline bovine serum albumin as standard.

Preparation of cell-free extracts. All purification steps and centrifugations were done at $4{ }^{\circ} \mathrm{C}$. Bacteria in the late-exponential phase of growth were harvested by centrifuging at $10000 \mathrm{~g}$, washed twice and finally resuspended in $20 \mathrm{~mm}$-Tris $/ \mathrm{HCl}$ buffer, pH 8.0 containing $10 \mathrm{~mm}-\mathrm{MgCl}_{2} \cdot 6 \mathrm{H}_{2} \mathrm{O}, 50 \mathrm{~mm}-\mathrm{NaHCO}_{3}, 5 \mathrm{~mm}-$ 2-mercaptoethanol and 1 mM-EDTA (TEMMB buffer) (Tabita \& McFadden, 1974a). The cell suspension was passed twice through a pre-chilled French press at $137 \mathrm{MPa}$ and unbroken cells and debris were removed by centrifuging at $10000 \mathrm{~g}$ for $10 \mathrm{~min}$. The supernatant was then centrifuged at $120000 \mathrm{~g}$ for $90 \mathrm{~min}$ to yield soluble and particulate fractions. The soluble fraction was the source of crude RuBP carboxylase.

Purification procedure. The crude soluble extract was slowly taken to $35 \%$ saturation with solid $\left(\mathrm{NH}_{4}\right)_{2} \mathrm{SO}_{4}$ and stirred for $30 \mathrm{~min}$. The precipitate was removed by centrifuging at $30000 \mathrm{~g}$ for $20 \mathrm{~min}$ and discarded. The supernatant was then taken to $60 \%$ saturation with $\left(\mathrm{NH}_{4}\right)_{2} \mathrm{SO}_{4}$ and stirred for $1 \mathrm{~h}$. After centrifuging at $30000 \mathrm{~g}$ for $20 \mathrm{~min}$, the pellet obtained was dissolved in TEMMB buffer and dialysed overnight against the same buffer. The enzyme solution was then applied to an Ultrogel AcA 22 column $(3.5 \times 100 \mathrm{~cm})$ equilibrated with TEMMB buffer. This was eluted at a flow rate of $10 \mathrm{ml} \mathrm{h}^{-1}$ and $5 \mathrm{ml}$ fractions were collected. Active fractions were pooled, taken to $60 \%$ saturation with $\left(\mathrm{NH}_{4}\right)_{2} \mathrm{SO}_{4}$ and stirred for $1 \mathrm{~h}$. Following centrifugation at $30000 \mathrm{~g}$ for $20 \mathrm{~min}$, the pellet was dissolved in TEMMB buffer and dialysed against the same buffer overnight. This solution was then applied to a DEAE-cellulose column $(2 \times 10 \mathrm{~cm})$ prewashed with Tris/ $\mathrm{HCl}$ buffer, $\mathrm{pH} 8.0$ containing $5 \mathrm{mM}-\mathrm{MgCl}_{2} \cdot 6 \mathrm{H}_{2} \mathrm{O}$ and $5 \mathrm{mM}-2$-mercaptoethanol (TMM buffer). Enzyme was eluted at a flow rate of $50 \mathrm{ml} \mathrm{h}^{-1}$ by a linear 0 to $1 \mathrm{M}-\mathrm{NaCl}$ gradient prepared in TMM buffer. Active fractions were pooled and concentrated in an Amicon ultrafiltration apparatus with an Amicon PM10 membrane. This enzyme solution $(2 \mathrm{ml})$ was finally loaded on to a discontinuous sucrose gradient (Tabita \& McFadden, 1974b) comprising four successive layers (each $14 \mathrm{ml}$ ) of $0.8,0.6,0.4$ and $0.2 \mathrm{M}$ sucrose in TEMMB buffer. After centrifugation at $80000 \mathrm{~g}$ for $24 \mathrm{~h}, 2 \mathrm{ml}$ fractions were collected by piercing the base of the tube. Active fractions were combined and concentrated by ultrafiltration.

Electrophoresis. Polyacrylamide gel electrophoresis (PAGE) was done using the discontinuous system of

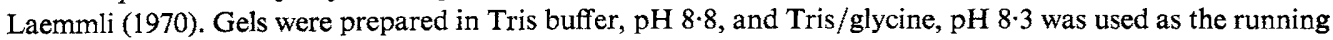
buffer. Where required, sodium dodecyl sulphate (SDS) at $0 \cdot 1 \%(\mathrm{w} / \mathrm{v})$ was incorporated into both buffers. Enzyme purity was assessed using non-denaturing gels polymerized from 4, 4.5, 5, 6 and $7 \cdot 5 \%(\mathrm{w} / \mathrm{v})$ acrylamide. Quaternary structure was determined by SDS-PAGE using $10 \%(\mathrm{w} / \mathrm{v})$ acrylamide gels or, for higher resolution, $7 \cdot 5$ to $20 \%$ (w/v) exponential gradient acrylamide gels (O'Farrell, 1975). Proteins were dissociated by boiling for $3 \mathrm{~min}$ in $1 \%$ (w/v) SDS plus $0 \cdot 1 \%(\mathrm{w} / \mathrm{v}) 2$-mercaptoethanol.

Determination of molecular weight. A Sephadex G-200 column $(1 \times 90 \mathrm{~cm})$ was equilibrated at $4{ }^{\circ} \mathrm{C}$ with TEMMB buffer and then a $0.5 \mathrm{ml}$ sample containing $R$. vannielii (RM5) RuBP carboxylase and marker proteins was applied to the column. The marker proteins were Escherichia coli $\beta$-galactosidase (mol. wt 
Table 1. Effect of carbon growth substrate on the specific activity of ribulose-1,5-bisphosphate carboxylase in crude extracts of Rhodomicrobium vannielii (RM5)

Unless otherwise indicated, substrates were each present at a final concentration of $10 \mathrm{~mm}$; $\mathrm{CO}_{2}$ was provided as filter-sterilized $\mathrm{NaHCO}_{3}$ (final concn $0.05 \%$, w/v). All cultures were harvested in the mid-exponential growth phase, determined by following the increase in $A_{540}$.

Carbon growth substrate

Sodium pyruvate

Sodium pyruvate $+\mathrm{CO}_{2}$

Sodium malate

Sodium succinate

Sodium pyruvate + sodium malate

Ethanol $+\mathrm{CO}_{2}$

Sodium butyrate $+\mathrm{CO}_{2}$

Sodium propionate $+\mathrm{CO}_{2}$

Sodium acetate $+\mathrm{CO}_{2}$

Sodium lactate $+\mathrm{CO}_{2}$

Hydrogen $(30 \%, v / v)+\mathrm{CO}_{2}$

\section{Specific activity}

[m units

(mg protein $\left.)^{-1}\right]$

$19 \cdot 3$

$19 \cdot 1$

$39 \cdot 2$

$25 \cdot 6$

$25 \cdot 7$

$20 \cdot 8$

$16 \cdot 8$

$16 \cdot 7$

$13 \cdot 1$

$15 \cdot 3$

$16 \cdot 0$

540000), horse spleen apoferritin (mol. wt 443000), beef liver glutamate dehydrogenase (mol. wt 320000), bovine liver catalase (mol. wt 232000), yeast alcohol dehydrogenase (mol. wt 141000) and E. coli alkaline phosphatase (mol. wt 86000) (Darnall \& Klotz, 1975). Proteins were eluted at a flow rate of $10 \mathrm{ml} \mathrm{h}^{-1}$ and $1 \mathrm{ml}$ fractions were collected. Enzymes were located by assaying fractions for activity and apoferritin was located by its absorbance at $412 \mathrm{~nm}$.

Determination of subunit molecular weights. This was done by SDS-PAGE using $10 \%(\mathrm{w} / \mathrm{v})$ acrylamide gels. The marker proteins were bovine serum albumin (mol. wt 67000), $\gamma$-globulins (mol. wts 25000 and 50000), ovalbumin (mol. wt 43500), horse heart myoglobin (mol. wt 16890) and horse heart cytochrome $c$ (mol. wt 13400).

Cation requirement. The requirement for a divalent cation for activity was examined using freshly purified enzyme dialysed overnight at $4{ }^{\circ} \mathrm{C}$ against $20 \mathrm{~mm}$-Tris/ $\mathrm{HCl}$ buffer, $\mathrm{pH} 8.0$ containing $5 \mathrm{mm-EDTA}$. The standard assay was then used, except that $\mathrm{Mg}^{2+}$ was replaced by other cations at final concentrations of $10 \mathrm{~mm}$.

Chemicals. All enzymes and biochemicals were of the highest grade available and obtained from Sigma. Chemicals were supplied by $\mathrm{BDH}$ and acrylamide came from Fluka.

\section{RESULTS}

\section{Levels of RuBP carboxylase}

The effect of carbon growth substrate on RuBP carboxylase activity in crude cell extracts of $R$. vannielii (RM5) was examined (Table 1). The highest specific activity [0.039 units (mg protein $)^{-1}$ ] was obtained after growth on malate. Extracts of cells grown on the reduced carbon substrates, butyrate and ethanol, had much lower RuBP carboxylase activities; however, growth on these substrates was poor.

\section{Purification of RuBP carboxylase}

The purification procedure adopted (Table 2 ) gave a $13 \%$ recovery of RuBP carboxylase with a final specific activity of 1.9 units (mg protein $)^{-1}$. Enzyme eluted from both Ultrogel AcA 22 and DEAE-cellulose columns as a single peak of activity indicating the presence of just one form of the enzyme. After sedimentation into a 0.8 to $0.2 \mathrm{M}$-sucrose gradient the enzyme was electrophoretically homogeneous, only one stained band being evident on gels polymerized from 4 to $7.5 \%(\mathrm{w} / \mathrm{v})$ acrylamide (Fig. 1). An overall 38 -fold purification from cell-free extracts indicates that the active protein constituted about $2.5 \%(\mathrm{w} / \mathrm{v})$ of the total soluble protein present in the $120000 \mathrm{~g}$ supernatant. 
Table 2. Purification procedure for ribulose-1,5-bisphosphate carboxylase from Rhodomicrobium vannielii (RM5)

\begin{tabular}{|c|c|c|c|c|}
\hline Purification step & $\begin{array}{l}\text { Protein } \\
(\mathrm{mg})\end{array}$ & $\begin{array}{l}\text { Activity } \\
\text { (units) }\end{array}$ & $\begin{array}{l}\text { Specific activity } \\
\text { [units } \\
\text { (mg protein)-1] }\end{array}$ & $\begin{array}{l}\text { Yield } \\
(\%)\end{array}$ \\
\hline $10000 \mathrm{~g}(10 \mathrm{~min})$ supernatant & 2100 & $56 \cdot 7$ & 0.027 & \\
\hline $120000 \mathrm{~g}(90 \mathrm{~min})$ supernatant & 1008 & 50 & 0.050 & 88 \\
\hline$\left(\mathrm{NH}_{4}\right)_{2} \mathrm{SO}_{4}$ precipitation (35 to $60 \%$ satn) & 446 & 37 & $0 \cdot 084$ & 66 . \\
\hline $\begin{array}{l}\text { Gel filtration on Ultrogel AcA } 22 \\
\text { (pooled and concd active fractions) }\end{array}$ & $49 \cdot 4$ & $28 \cdot 3$ & 0.57 & 49 . \\
\hline $\begin{array}{l}\text { DEAE-cellulose chromatography (pooled } \\
\text { and concd active fractions) }\end{array}$ & $14 \cdot 0$ & $21 \cdot 0$ & $1 \cdot 5$ & 37 \\
\hline Sucrose gradient $(0.2$ to $0.8 \mathrm{M})$ & 3.9 & $7 \cdot 4$ & $1 \cdot 9$ & $13 \cdot 0$ \\
\hline
\end{tabular}

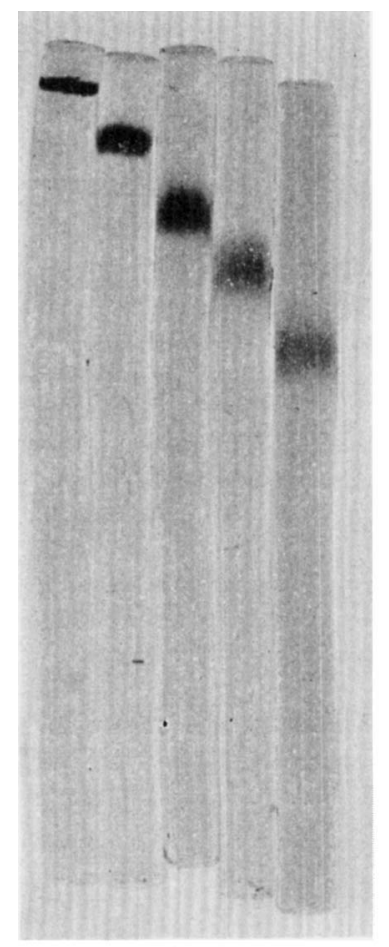

Fig. 1

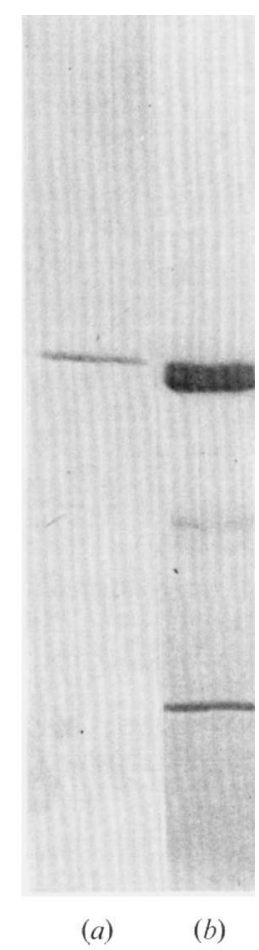

Fig. 2

Fig. 1. Polyacrylamide gel electrophoresis of Rhodomicrobium vannielii (RM5) ribulose-1,5-bisphosphate carboxylase. A $50 \mu \mathrm{g}$ sample was applied to each gel polymerized from (left to right) $7 \cdot 5,6,5,4 \cdot 5$ and $4 \%(w / v)$ acrylamide.

Fig. 2. SDS-polyacrylamide gel electrophoresis $[7.5$ to $20 \%(\mathrm{w} / \mathrm{v})$ exponential gradient acrylamide gel] of purified Rhodomicrobium vannielii (RM5) ribulose-1,5-bisphosphate carboxylase (a) following storage for $14 \mathrm{~d}$ at $4{ }^{\circ} \mathrm{C}$ after $\left(\mathrm{NH}_{4}\right)_{2} \mathrm{SO}_{4}$ treatment $(30 \mu \mathrm{g}$ protein) and $(b)$ without storage $(45 \mu \mathrm{g}$ protein). The enzyme in $(a)$ and $(b)$ was derived from the same batch of cell-free extract.

\section{Molecular weight of RuBP carboxylase}

The molecular weight was determined by gel filtration as described in Methods. A value of 430000 was obtained using both pure enzyme and partially purified material (after $\left(\mathrm{NH}_{4}\right)_{2} \mathrm{SO}_{4}$ precipitation).

Quaternary structure of $R$ RBP carboxylase

Rhodomicrobium vannielii (RM5) RuBP carboxylase was dissociated by SDS in the presence of 2-mercaptoethanol into three types of polypeptide as revealed by SDS-PAGE 
Table 3. Effect of various cations on the activity of purified Rhodomicrobium vannielii (RM5) ribulose-1,5-bisphosphate carboxylase

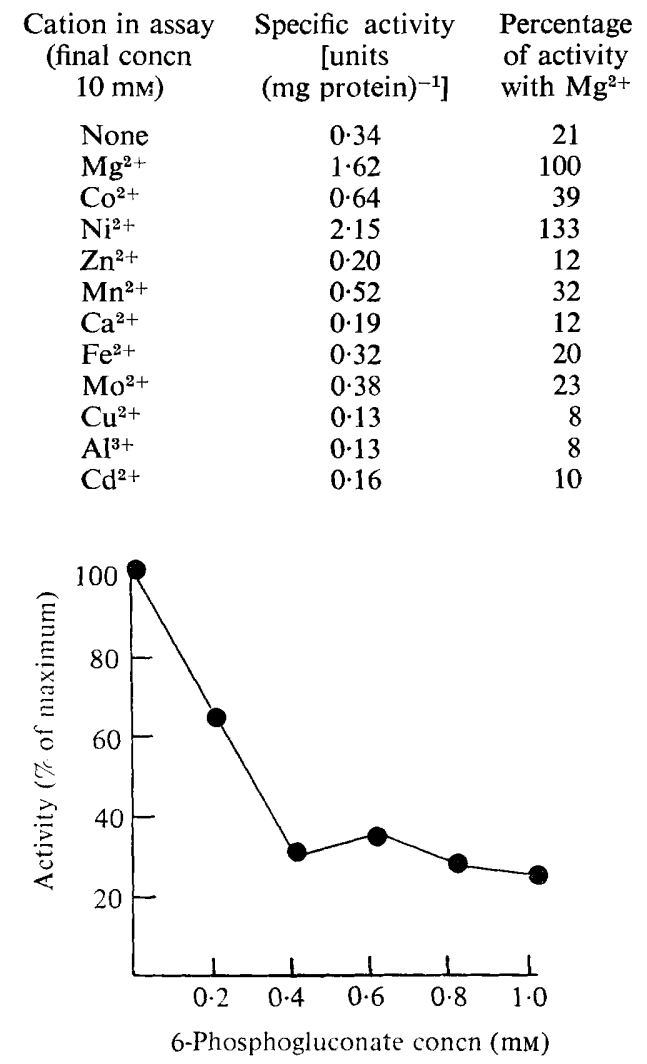

Fig. 3. Effect of 6-phosphogluconate on the activity of Rhodomicrobium vannielii (RM5) ribulose1,5-bisphosphate carboxylase. The maximum activity was 1.9 units (mg protein) ${ }^{-1}$.

on 7.5 to $20 \%$ (w/v) exponential gradient gels (Fig. $2 b$ ). Two slowly moving bands of similar mobility indicated two types of large polypeptide subunit and a faster moving band indicated a small polypeptide subunit. Some preparations contained a minor protein contaminant of molecular weight intermediate between the large and small polypeptides, although this may have represented associated subunits. Molecular weights of the polypeptides were 56200, 53300 and 15700 when measured as described in Methods. An approximate mole ratio of the subunits was determined by scanning the stained bands on gels at $656 \mathrm{~nm}$. The average ratio of small to total large subunits was $1: 1 \cdot 14$. With a molecular weight of 430000 , the most likely quaternary structure of this enzyme consists of six large and six small subunits. During purification, some enzyme preparations were stored for up to one month at $4{ }^{\circ} \mathrm{C}$ following 35 to $60 \%\left(\mathrm{NH}_{4}\right)_{2} \mathrm{SO}_{4}$ precipitation. The subunit composition of enzyme purified following storage for $14 \mathrm{~d}$ was also examined by SDS-PAGE (Fig. $2 a$ ). Heterogeneity of the large subunit was not evident and, furthermore, no small polypeptide subunits were detected. The specific activity of this pure enzyme preparation was 0.7 units (mg protein) $)^{-1}$.

\section{Catalytic properties}

The purified enzyme was fully stable for at least 1 month when stored at $-80{ }^{\circ} \mathrm{C}$. Activity was lost during storage at either 4 or $-20{ }^{\circ} \mathrm{C}$, only $50 \%$ of the initial activity remaining after $21 \mathrm{~d}$. 
Maximum enzyme activity was dependent on the presence of a divalent cation (Table 3 ). The reaction was not specific for $\mathrm{Mg}^{2+}$, with $\mathrm{Mn}^{2+}, \mathrm{Co}^{2+}$ and $\mathrm{Ni}^{2+}$ giving 32, 39 and $133 \%$, respectively, of the activity with $\mathrm{Mg}^{2+}$.

\section{Effect of 6-phosphogluconate on enzyme activity}

6-Phosphogluconate has been shown to inhibit RuBP carboxylases from various sources (Tabita \& McFadden, 1972), sensitive enzymes having a molecular weight of approximately 500000. When added to the assay mixture simultaneously with RuBP, 6-phosphogluconate inhibited $R$. vannielii (RM5) RuBP carboxylase, the enzyme having only $50 \%$ of its original activity in the presence of $0.3 \mathrm{~mm}-6$-phosphogluconate (Fig. 3).

\section{DISCUSSION}

The derepression of RuBP carboxylase synthesis following growth with butyrate as carbon substrate, as reported for Rhodospirillum rubrum (Tabita \& McFadden, 1974a), Rhodopseudomonas sphaeroides (Gibson \& Tabita, 1977a) and Rhodopseudomonas capsulata (Gibson \& Tabita, 1977b), was not observed in Rhodomicrobium vannielii (RM5). The specific activity of RuBP carboxylase in cell-free extracts of malate-grown cells was, however, some five-fold greater than the equivalent activity reported for Rhodospirillum rubrum (Tabita \& McFadden, 1974a). These results may be indicative of a different mechanism of regulation of $\mathrm{CO}_{2}$ fixation in Rhodomicrobium vannielii from that in other Rhodospirillaceae.

The requirement for a divalent cation for activity is consistent with data for all other RuBP carboxylases that have been investigated. With plant RuBP carboxylases, substitution of $\mathrm{Mg}^{2+}$ by $\mathrm{Ni}^{2+}$ or $\mathrm{Co}^{2+}$ has been shown to depend on the age and purity of the enzyme preparation (Kawashima \& Wildman, 1970). The high activity of freshly isolated Rhodomicrobium vannielii carboxylase, assayed in the presence of $\mathrm{Ni}^{2+}$, may be novel and is particularly interesting in view of the reported specificity of the Rhodospirillum rubrum enzyme for $\mathrm{Mg}^{2+}$ (Tabita \& McFadden, 1974a).

Two types of large polypeptide subunit in the pure Rhodomicrobium vannielii (RM5) RuBP carboxylase were clearly resolved by electrophoresis of dissociated enzyme on exponential gradient acrylamide gels. Large subunit heterogeneity has previously been reported to occur in the RuBP carboxylases of tobacco (Kung et al., 1974) and Hydrogenomonas eutropha (Purohit et al., 1976) (being evident in Hydrogenomonas in the presence of protease inhibitors). Proteolysis, however, cannot be ruled out as a possible cause of heterogeneity of the Rhodomicrobium vannielii carboxylase, particularly in view of the apparent instability of its quaternary structure. The loss of the small polypeptide subunits during storage may be compared with the reported loss of the small subunits from the Aphanocapsa RuBP carboxylase on acid precipitation (Codd \& Stewart, 1977) and suggests a relatively weak quaternary structure. Although enzyme activity did decrease on storage, the presence of some activity despite loss of detectable small subunits, suggests that the catalytic activity of the Rhodomicrobium vannielii RuBP carboxylase resides with the large subunits, as has been found with the carboxylases of Chromatium (Takabe \& Akazawa, 1973) and Aphanocapsa (Codd \& Stewart, 1977).

Apart from the Rhodomicrobium vannielii carboxylase, the only other RuBP carboxylases so far found that probably comprise six large and six small subunits are those of Pseudomonas oxalaticus (McFadden, 1977) and Methylococcus capsulatus (Bath) (Taylor, 1977, 1979). Elucidation of the spatial arrangement of the subunits in these carboxylases merits further investigation.

Results presented here have demonstrated the instability of the quaternary structure of the Rhodomicrobium vannielii (RM5) RuBP carboxylase. This may explain the reported 
presence of two forms of the enzyme in Rhodopseudomonas sphaeroides (Gibson \& Tabita, 1977 a) and Rhodopseudomonas capsulata (Gibson \& Tabita, 1977b) where one form lacks detectable small polypeptide subunits. Care should therefore be taken in the determination of RuBP carboxylase structure.

\section{REFERENCES}

Akazawa, T., Kondo, H., Shimazue, T., Nishimura, M. \& SugiYama, T. (1972). Further studies on ribulose 1,5-diphosphate carboxylase from Chromatium strain D. Biochemistry 11, 1298-1303.

Bassham, J. A., Benson, A. A., Kay, L. D., Harris, A. Z., Wilson, A. T. \& Calvin, M. (1954). The path of carbon in photosynthesis. XXI. The cyclic regeneration of carbon dioxide acceptor. Journal of the American Chemical Society 76, 1760-1770.

Codd, G. A. \& Stewart, W. D. P. (1977). Polyhedral bodies and ribulose 1,5-diphosphate carboxylase of the blue-green alga Anabaena cylindrica. Planta 130, 323-326.

Darnal., D. W. \& Klotz, I. M. (1975). Subunit constitution of proteins: a table. Archives of Biochemistry and Biophysics 166, 651-682.

FranCE, A. D. (1978). Morphogenesis and differentiation in Rhodomicrobium. Ph.D. thesis, University of Warwick.

Gibson, J. L. \& TABITA, F. R. (1977a). Different molecular forms of D-ribulose-1,5-bisphosphate carboxylase from Rhodopseudomonas sphaeroides. Journal of Biological Chemistry 252, 943-949.

Gibson, J. L. \& TABITA, F. R. (1977b). Isolation and preliminary characterisation of two forms of ribulose 1,5-bisphosphate carboxylase from Rhodopseudomonas capsulata. Journal of Bacteriology, 132, 818-823.

KaWASHima, N. \& Wildman, S. G. (1970). Fraction1 protein. Annual Review of Plant Physiology 21, 325-358.

Kennedy, S. I. T. \& Fewson, C. A. (1968). Enzymes of the mandelate pathway in bacterium NCIB 8250. Biochemical Journal 107, 497-503.

Kung, S. D., Sakano, K. \& Wildman, S. G. (1974). Multiple peptide composition of the large and small subunits of Nicotiana tabacum fraction 1 protein ascertained by fingerprinting and electrofocusing. Biochimica et biophysica acta $\mathbf{3 6 5}$, 138-147.

LAemmLi, U. K. (1970). Cleavage of structural proteins during the assembly of the head of bacteriophage T4. Nature, London 227, 680-685.

MCFADDEN, B. A. (1973). Autotrophic $\mathrm{CO}_{2}$ assimilation and the evolution of ribulose diphosphate carboxylase. Bacteriological Reviews 37, 289-319.

MCFAdDEN, B. A. (1977). Evolution of the Calvin cycle - an analysis of RuBP carboxylase/oxygenase. In Microbial Growth on $C_{1}$ Compounds, 2nd International Symposium Pushchino, USSR, pp. 106-107. Pushchino: USSR Academy of Science.

MCFAdden, B. A. \& TAbita, F. R. (1974). 1)Ribulose-1,5-diphosphate carboxylase and the evolution of autotrophy. Biosystems 6, 93-112.

O'Farrell, P.H. (1975). High resolution twodimensional electrophoresis of proteins. Journal of Biological Chemistry 250, 4007-4021.

Purohit, K., McFadden, B. A. \& Cohen, A. L.
(1976). Purification, quaternary structure, composition and properties of D-ribulose-1,5-bisphosphate carboxylase from Thiobacillus intermedius. Journal of Bacteriology 127, 505-515.

TABitA, F. R. \& McFadDen, B. A. (1972). Regulation of ribulose-1,5-diphosphate carboxylase by 6-phospho-D-gluconate. Biochemical and Biophysical Research Communications 48, 1153-1159.

TABITA, F. R. \& MCFAdDEN, B. A. (1974a). D-Ribulose 1,5-diphosphate carboxylase from Rhodospirillum rubrum. I. Levels, purification and effects of metallic ions. Journal of Biological Chemistry 249, 3453-3458.

Tabita, F. R. \& McFadden, B. A. (1974b). D-Ribulose 1,5-diphosphate carboxylase from Rhodospirillum rubrum. II. Quaternary structure, composition, catalytic and immunological properties. Journal of Biological Chemistry 249, 3459-3464.

Tabita, F. R. \& McFadden, B. A. (1976). Molecular and catalytic properties of ribulose 1,5bisphosphate carboxylase from the photosynthetic extreme halophile Ectothiorhodospira halophila. Journal of Bacteriology 126, 1271-1277.

TAbita, F. R., McFadden, B. A. \& Pfennig, N. (1974a). D-Ribulose-1,5-bisphosphate carboxylase in Chlorobium thiosulfactophilum Tassajara. Biochimica et biophysica acta 341, 187-194.

Tabita, F. R., Stevens, S. E. \& QuiJano, R. (1974b). D-Ribulose-1,5-diphosphate carboxylase from blue-green algae. Biochemical and Biophysical Research Communications 61, 45-52.

Tabita, F. R., Stevens, S. E. \& Gibson, J. L. (1976). Carbon dioxide assimilation in blue-green algae: initial studies on the structure of ribulose 1,5bisphosphate carboxylase. Journal of Bacterio$\log y$ 125, 531-539.

Takabe, T. M. \& Akazawa, T. (1973). Catalytic role of subunit $A$ in ribulose 1,5-diphosphate carboxylase from Chromatium strain D. Archives of Biochemistry and Biophysics 157, 303-308.

TakaBe, T. M., Nishimura, M. \& AkazaWa, T. (1976). Presence of two subunit types in ribulose1,5-bisphosphate carboxylase from blue-green algae. Biochemical and Biophysical Research Communications 68, 537-544.

TAYLOR, S. C. (1977). Evidence for the presence of ribulose 1,5-bisphosphate carboxylase and phosphoribulokinase in Methylococcus capsulatus (Bath). FEMS Microbiology Letters 2, 305-307.

TAYLOR, S. C. (1979). Ribulose 1,5-bisphosphate carboxylase and carbon dioxide fixation in Rhodomicrobium vannielii (RM5) and Methylococcus capsulatus (Bath). Ph.D. thesis, University of Warwick.

Whittenbury, R. \& Dow, C. S. (1977). Morphogenesis and differentiation in Rhodomicrobium vannielii and other budding and prosthecate bacteria. Bacteriological Reviews 41, 754-808. 